FORSKNING

\title{
Hva er god publiseringsetikk?
}

Publiseringsetikk handler om forfatteres, fagfellers og redaktørers integritet.

\section{Forfattere}

Kristin Halvorsen

1. amanuensis

Sykepleien Forskning 2014 9(1)(90-91)

DOI: https://doi.org/10.4220/sykepleienf.2014.0076

Et viktig aspekt ved forskningsetikk er publiseringsetikk $(1,2)$. Forfattere, redaktører og forlag er ansvarlige for å presentere lesere for forskning som er ny, original, redelig og valid. Publiseringsetiske hensyn gjelder ved all publisering, enten det er i papirformat, eller online (3). I dagens akademia er publisering av vitenskapelige arbeider et krav. Akademikere, universiteter og høyskoler måles i stor grad på bakgrunn av sin vitenskapelige produksjon (2). Det er ingen tvil om at dette publikasjonskravet nødvendiggjør et skarpt og kontinuerlig blikk på publiseringsetikk (2). På den annen side er forskningen avhengig av publisering. Det er gjennom publisering at forskningsresultater blir formidlet til omverdenen (4). Den internasjonale komiteen COPE (Comitte of Publication Ethics) får hvert år inn saker der det er spørsmål om brudd på publiseringsetiske retningslinjer (5). Andre liknende komiteer; ICE, ICMJE, ORI, WAME rapporterer tilsvarende (6). Det er heldigvis sjelden, men av og til forekommer det graverende forskningsfusk og lovbrudd (7). Noen ganger publiseres det forskning som befinner seg i gråsonen for hva som er god publiseringsetikk. Jeg vil her belyse noen av de publiseringsetiske utfordringene som kan oppstå.

\section{Forfatterskap}

Et sentralt tema i publiseringsetikk er forfatterskap og medforfatterskap. Her skal Vancouver-reglene være en rettesnor for hva som kvalifiserer til å være artikkelforfatter og medforfatter (8). Det viser seg likevel at det er store forskjeller i hvordan regelverket praktiseres innenfor ulike forskningsgrupper og forskningsmiljøer $(4,9,10)$. Staff og Thorseth problematiserer i en kommentar i Tidsskrift for Norsk Legeforening i 2007, hvordan veilederes medforfatterskap kan skape dilemmaer for masterstudenter og ph.d-stipendiater og at praksisen for forfatterskap er forskjellig fra universitet til universitet i Norge (9). I dag er det en økende praksis at masteroppgaver publiseres som artikler. Dette skyldes blant annet et ønske om å øke publiseringsraten i akademia, samt at studiene kan bli tilgjengelig for flere. Et nødvendig tiltak for å unngå uheldige situasjoner i forbindelse med forfatterskap er at forfatterrekkefølgen diskuteres i fagmiljøene. Det må framgå tydelig hva de ulike forfatterne har bidratt med i forskningsprosessen og i arbeidet med selve artikkelen. I tillegg må alle forfattere godkjenne den endelige versjonen av artikkelen $(3,4,9,10)$.

\section{Medforfattere}


De fleste tidsskrifter krever i dag at de enkelte forfatternes bidrag skal synliggjøres, slik at redaktører og fagfeller kan ta stilling til den enkelte forfatterens innsats. Ikke sjelden har vitenskapelige artikler mange forfattere. Dette kan være et resultat av store og landsomfattende forskningsprosjekter, der mange skal ha sin del av forskningen. Her kan det oppstå uheldige koplinger med hensyn til medforfatterskap. Enkelte tidsskrifter har satt en øvre grense på seks medforfattere, nettopp for å unngå medforfattere som ikke tilfredsstiller Vancouver-reglenes krav til medforfatterskap $(6,8)$. Forfatterne oppfordres til å skille mellom de som kvalifiserer til medforfatterskap og de som kan anerkjennes i artikkelens etterord $(1-5,7,9,10)$. Forfatterskap skal være noe man har gjort seg fortjent til på bakgrunn av arbeidet man har nedlagt i prosessen fra prosjektidé til publikasjon. (3).

\section{Dobbeltpublisering}

Et tema som skaper publiseringsetiske utfordringer er dobbeltpublisering. Dobbeltpublisering vil si at en originalpublikasjon kan komme til å bli publisert i flere enn én publikasjonskanal. Som en grunnregel er dobbeltpublisering ikke ønskelig, men kan i enkelte tilfeller forekomme etter tillatelse fra tidsskriftet som har rettighetene til publikasjonen. Hvis man tillater en form for dobbel, eller sekundær publisering er det et absolutt krav at kryssrefereringen er tydelig og klar, slik at leserne uten problemer kan ledes til den opprinnelige referansen (1-4).

\section{«Salami-slicing»}

Forskere ønsker gjerne å få flest mulig publikasjoner ut av eget prosjekt. Dette kan resultere i «salami-slicing», og at ulike publikasjoner kan tendere til å bli overlappende. Det vil således være mulig for lesere og brukere av forskningen, å bli misledet med hensyn til forskningsfunnenes originalitet og styrke. Dobbeltpublisering og «salami-slicing» kan videre føre til at forskningsresultater blir benyttet på uriktig grunnlag, der det kan se ut som flere studier viser samsvarende funn, men egentlig er funn fra samme studie (1-3).

\section{Plagiering}

Plagiering er alvorlig. En innlysende form for plagiering er når man med overlegg stjeler av andres forskningsmateriale. Dette er et klart publiseringsetisk brudd (1-5). Noe annet som kanskje ikke alltid synes like opplagt er når det benyttes tabeller, oversikter, sitater eller annet materiale fra andre publikasjoner uten tilstrekkelig referanser og skriftlig tillatelse fra tidsskriftet som har utgitt originalpublikasjonen. For eksempel er det ikke akseptabelt å bruke andre forskeres modeller i eget arbeid uten skriftlig tillatelse fra tidsskriftet, og om mulig fra forskeren som har utviklet modellen $(3,10)$.

\section{Interessekonflikter}

Interessekonflikter handler ofte om en risiko for at finansieringskilden ikke er nøytral $(1-4,10)$. Her er legemiddelindustrien utpekt som «den store stygge ulven». Legemiddelindustrien har fått mye kritikk for å involvere seg som «spøkelser» i forskningen den støtter (11). Men, det er viktig å være klar over at det finnes flere former for interessekonflikter. Et overordnet mål må være at det i hele forskningsprosessen, fra idé til publikasjon, ikke er ytre hensyn som kommer i konflikt med forskningens troverdighet (10). 


\section{Referanser}

1. Cristakis AD, Rivara PR. Publication Ethics: Editors perspectives. Journal of Pediatric 2006;149:39-42.

2. Robinson JA. Bad Science and Publication ethics. Editorial. International Nursing Rewiev 2009;56:276.

3. Carlson K, Ross J. Publication Ethics: Conflicts, Copyright, Permission, and Authorship. Journal of PeriAnesteshesia Nursing 2010; 25:263-71.

4. Staff A, Rørtveit G. Publiseringsetikk - et felles ansvar. Tidsskrift for Norske Legeforening. 2010; 3:130.

5. COPE, Committee on Publication Ethics, http://publicationethics.org/ (lasted ned 16.10.2013).

6. Roberts J. An Author's guide to Publication Ethics: A Review of Emerging Standards in Biomedical Journals. Headache 2009;49:578-89.

7. Kluge L, Hafstad A, Torp IS, Jon Sudbø. Aftenposten. A magasinet 27.1.2006 http://www.aftenposten.no/amagasinet/article1207468.ece (lasted ned 1.11.2013)

8. Vancouver Protocol http://www.research.mq.edu.au/about/research_@_macquarie/policies,_procedures_and_conduct/documents/Vancouver.pdf (lastet ned 1.11.2013)

9. Staff A, Thorseth M. Hva er en medforfatter. Tidsskrift for Norsk Legeforening 2007;15;127.

10. Wagner E, Barbour V, Yentis S, Kleinert S, on behalf of COPE Council. Retractions: Guidance from the Committee on Publication Ethics. Journal of Critical Care 2009;24:620-2.

11. Sismondo S, \& Doucet M. Publication ethics and the ghost management of medical publication. Bioethics 2010; 24 273-83. 